\title{
A strategy for increased public transport usage: The effects of implementing a welfare maximizing policy
}

\author{
Johan Holmgren
}

\section{Linköping University Post Print}

\section{Tweet}

N.B.: When citing this work, cite the original article.

Original Publication:

Johan Holmgren , A strategy for increased public transport usage: The effects of implementing a welfare maximizing policy, 2014, Research in Transportation Economics, (48), 221-226. http://dx.doi.org/10.1016/j.retrec.2014.09.046

Copyright: Elsevier http://www.elsevier.com/

Postprint available at: Linköping University Electronic Press

http://urn.kb.se/resolve?urn=urn:nbn:se:liu:diva-112962 


\title{
A strategy for increased public transport usage - The effects of implementing a welfare maximizing policy
}

\author{
Johan Holmgren ${ }^{\text {a* }}$ \\ ${ }^{a}$ Division of Communications and Transport systems, Dep. of Science and Technology, Linköping University, Sweden \\ * Corresponding author: Department of Science and Technology, Linköping University, SE-601 74, Norrköping, Sweden, +46 \\ (0)113636 05, johan.holmgren@liu.se
}

\author{
Keywords \\ Demand \\ Supply \\ Public transport \\ Price \\ Fare \\ Optimization \\ Welfare \\ Policy
}

\section{ABSTRACT}

For a long time public transport has experienced a struggle against rising costs and increasing car ownership. So far, public transport appears to be on the losing side in terms of market shares. The aim if this paper is to investigate if a different policy could result in higher public transport usage and improved social welfare. In order to achieve this, a model, explaining public transport usage, public transport supply and costs, is estimated. The model is then used in order to simulate the outcome of an alternative policy of social welfare maximization. It is found that the current policy of the Swedish transport is not efficient in terms of maximizing welfare. In 2011, public transport fares should have been lower in 20 of 21 counties and the supply of vehicle kilometres should have been higher in 17 of 21 counties. Implementing a welfare maximizing policy would have increased the number of trips per capita by $17.2 \%$ in 2011 and by an average of $6.7 \%$ for the period $1986-2011$.

\section{Introduction}

Transport policy in Sweden, as well as in many countries, states that the transport system should be designed in order to contribute to a shift towards a sustainable society. An important part of the official policy is that pricing in the transport sector should be efficient, i.e. prices should equal marginal costs (including environmental costs caused by transportation) and that changes in the transport system (including investments) should be appraised through the use of cost-benefit analysis. It is also concluded that if the environmental strain caused by the transport system is to be reduced, public transport needs to gain market shares at the expense of the private car. (prop. 2008/09:93) Despite this, the private car has long time gained market shares at the expense of public transport in Sweden as well as in most areas in Europe.

At a strategic level, the primary means of affecting demand at the disposal of the transport supplier is changes in price and service levels. From a policy viewpoint, the balance between fare and service level (in combination with subsidy level) constitutes the fundamental 
strategic decision. Privately owned producers would probably try to maximize their profits unless regulated. Since public transport in Sweden is publicly controlled and heavily subsidized, the producer's goal should be social welfare maximization. (See e.g. Layard and Walters, 1978 or Zerbe and Dively, 1994 for textbook discussions of welfare theory) ${ }^{1}$ The aim of this paper is to evaluate the policy of the Swedish public transport authorities (PTA:s), in terms of fare and supply level, in order to determine if it is efficient, i.e. maximizing the welfare generated from the public transport system. If this is not the case, the paper will also aim at showing what changes such policy would require as well as the results of such policy. The study is of local and regional public transport over which the PTA:s have authority, henceforth in the paper when using the term public transport it refers to local and regional public transport.

The present study uses annual data from 27 Swedish counties from 1986 to 2011. Data are aggregated at a county level. Due to changes in the county structure and missing data, there is a total of 702 usable observations. The data concerning patronage, vehicle-kilometres, costs, and fares are supplied by the Swedish Public Transport Association (Svensk Kollektivtrafik) and Transport Analysis (Trafikanalys) to which local transport authorities report several key statistics. Data on income, population, and car ownership were obtained from Statistics Sweden (SCB).

The next section offers a brief description of the public transport system in Sweden and an overview of the development of public transport in Sweden. In section 3, a model of the public transport system is presented whilst section 4 presents the conditions for welfare maximization and implements the empirical results from section 3 in order to draw conclusions on the optimal fare and supply level. In the last section the results are discussed and conclusions are presented.

\section{Development of public transport in Sweden}

In 1979 a major organizational reform of the Swedish public transport sector took place. It was a reform that since then has had a profound impact on the workings of the local and regional public transport system. It required a Public Transport Authority (PTA) to be established in each county. The PTA:s are most commonly owned by the municipalities and the county council jointly, and were up to the beginning of 2012 responsible for the coordination of public transport operations in the counties. (Act 1978:438) In 1985 the PTA:s were also given the responsibility of issuing licenses for operating public transport services within the county and in practice it meant that they had the options of (1) performing the services themselves, in house, i.e. acting as an operator themselves or (2) contracting out the service to private companies. In this context, it should be mentioned that before the reform of 1979, public transport services were provided by a mixture of private and publicly owned firms. Before 1960 the sector was dominated by private companies operating without subsidies but increased costs and rising car ownership resulted in many of them being taken over by municipality owned companies during the 1960:s and 1970:s. These companies (including the municipally owned) all operated independently without coordination of fares and service. (Jansson and Wallin, 1991, Alexandesson, 2010)

\footnotetext{
${ }^{1}$ For discussions of different management objectives and their effects, see Bös (1978), Glaister and Collings (1978), Nash (1978), and Webster and Bly (1980).
} 
The most important change 1979 was that the fares was coordinated and subsidized trough the PTA:s. (Jansson and Wallin, 1991, Alexandesson, 2010) After 1985, the PTA:s gradually started to implement competitive tendering of the operations. Since then, the proportion of traffic procured through competitive tendering has levelled out around $95 \%$ with some municipalities still operating some special transport services and school transports themselves. (Alexandesson, 2010)

Despite relying on private companies to perform the actual operations, the PTA:s has retained all network planning as well as decisions on frequency and fares. They have also regulated what kind of vehicles that should be used and what standard they should have. The operators have worked under gross contracts with no influence over actual operations. (Alexandesson, 2010) In terms of Macario (2001) the Swedish system can be characterized as one in which the authorities have almost all influence and initiative and the operators almost none. (See also Hansson, 2011, who discuss the dominant influence of the PTAs in the Swedish system.)

As mentioned before, an important goal of the Swedish transport policy is to increase public transport usage and (some of) the figures presented in figure 1 are usually used to claim some success in that regard.

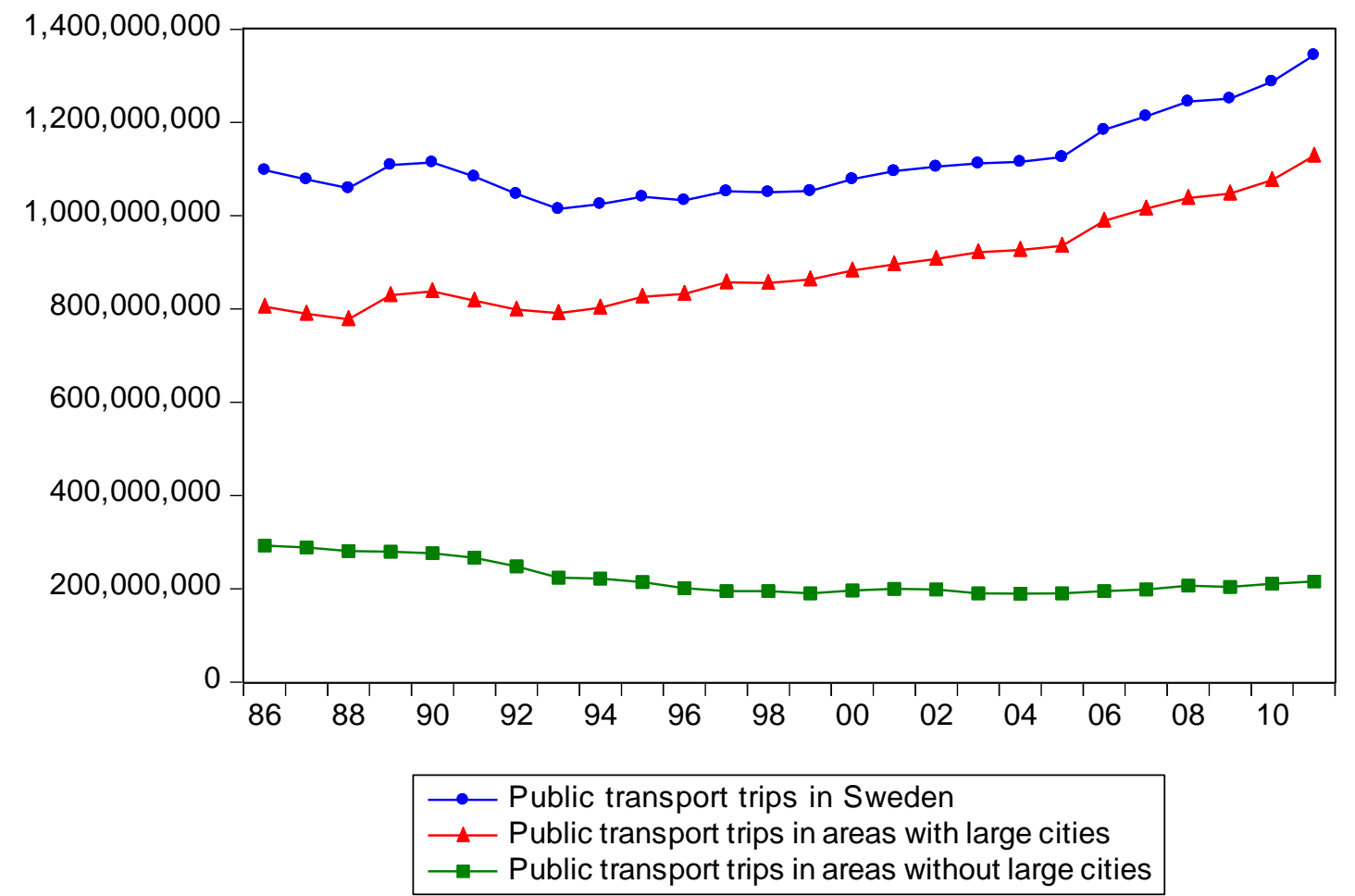

Figure 1. Number of public transport trips in Sweden 1986-2011.

The figure show the number of trips made in local and regional public transport in Sweden 1986-2011. However, as can also be seen in the figure, the positive development is almost totally generated in the three counties containing Sweden's largest cities, i.e. Stockholm,

\footnotetext{
${ }^{2}$ Areas with large cities refer to large cities refer to Stockholm, Västra götaland and Skåne in which the cities Stockholm, Gothenburg and Malmö are situated. Data obtained from the Swedish Public Transport Association and the governmental agency Transport analysis.
} 
Västra götaland and Skåne (in which the cities Stockholm, Gothenburg and Malmö are situated). Those counties are represented by the middle line in the figure while the lower line shows the development in the rest of Sweden.

Looking at total numbers gives part of the picture as totals might hide the fact that some of the development is due to changes in population and not usage per person. In figure 2, the development in local and regional public transport trips per capita is shown. The differences between the large cities and the rest of the country are even more apparent in this case. Outside Stockholm, Västra göraland and Skåne, the number of trips per capita has been falling compared to the eighties. In fact, in 19 of the 27 counties, number of trips per capita reached its peak during 1986-1990 (12 in 1986).

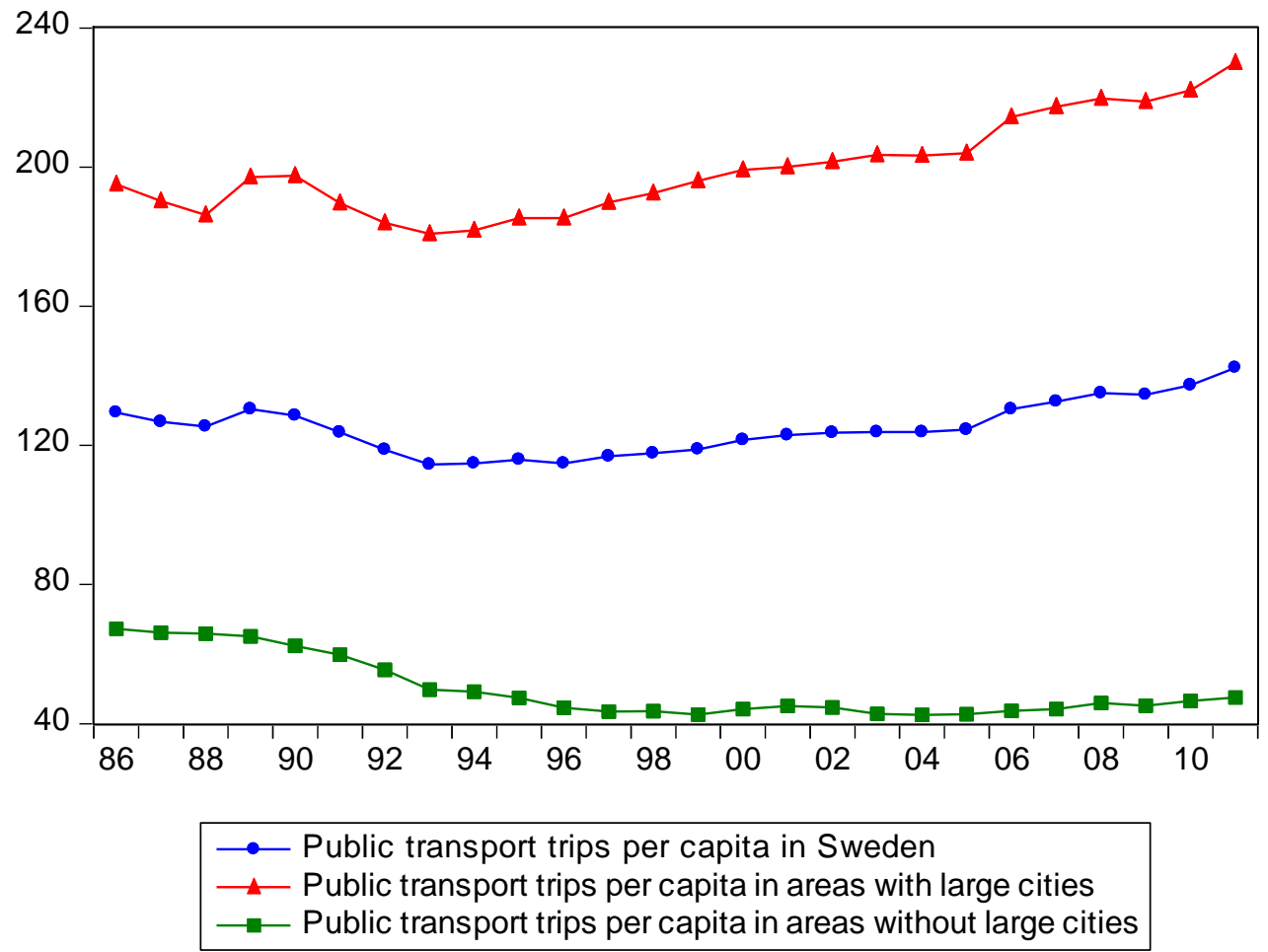

Figure 2. Public transport trips per capita in Sweden $1986-2011 .^{3}$

As one of the central policy relevant factors affecting public transport usage, the effect of fare changes has been studied extensively. (e.g. Webster and Bly, 1980, Goodwin, 1992, Balcombe, et.al. 2004, Holmgren, 2007) From figure 3, it can be seen that during the studied period (1986-2011), public transport fares in Sweden have changed quite a lot, even after removing the effects of inflation. ${ }^{4}$ In the counties containing the largest cities, real fares $(2012$ prices) was increased by $68 \%$ between 1986 and 2011, while the corresponding figure for the rest of the country was $93 \%$. It is therefore evident that the public transport users in the larger cities as well as outside those areas pay significantly more per trip now than before.

\footnotetext{
${ }^{3}$ See footnote 2 .

${ }^{4}$ Fares are approximated by revenue per trip. 1 SEK $=0.11 €$ (July 2013)
} 


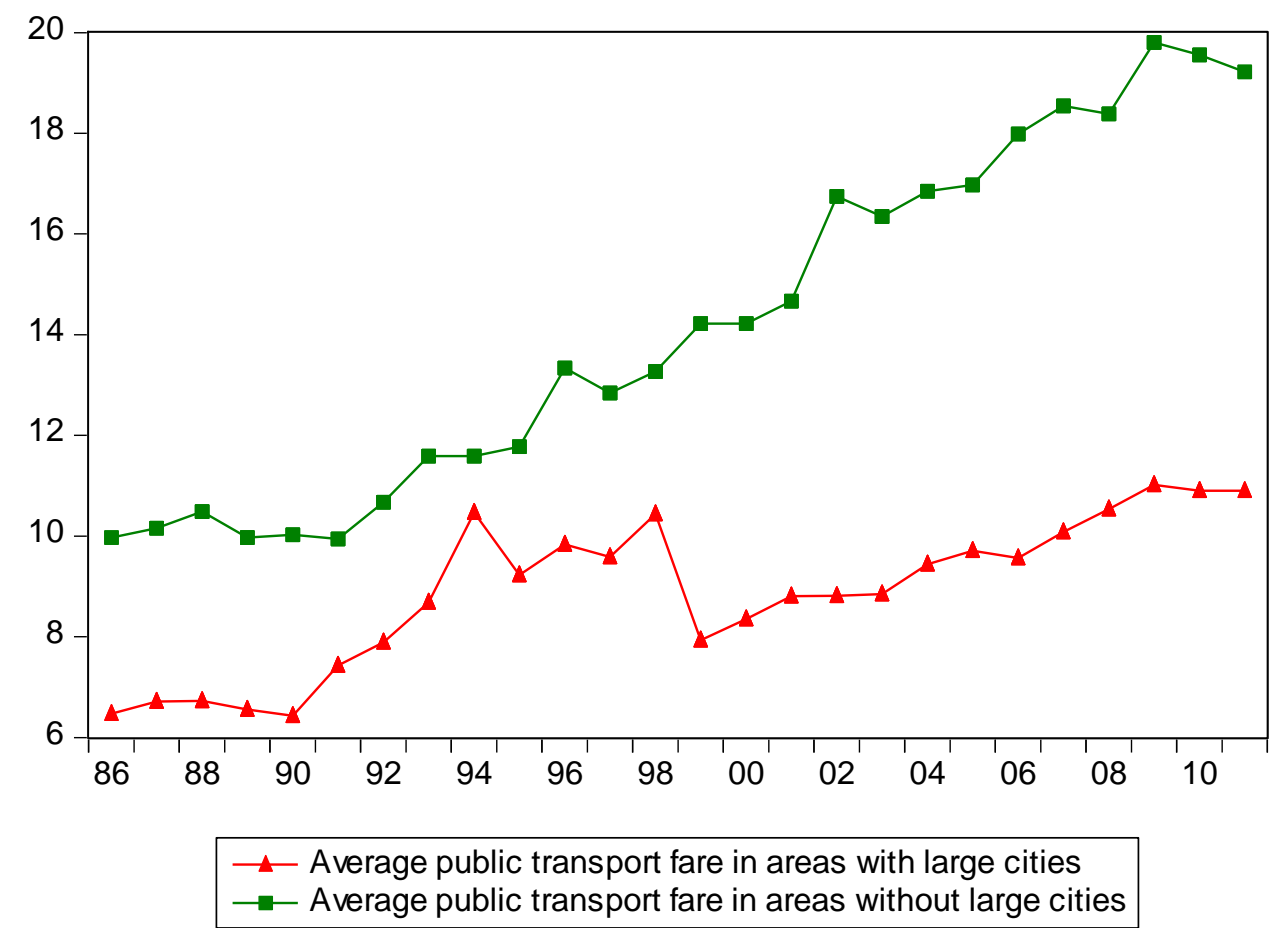

Figure 3. Real public transport fares in SEK (2012 price level) in Swedish counties $1986-2011 .^{5}$ 1 SEK $=0.11 €($ July 2013)

\section{Public transport demand - a model}

In order to explain the development shown in figures 1 and 2 and the predict changes due to an alternative policy, a model of the public transport sector is estimated. The model consists of a demand function (1), a cost function (2) a capacity constraint (3) and a supply adjustment function.

Nelson (1972), among others, argue that the fare elasticity $\left(E_{F}\right)^{6}$ should increase with fares. The rationale for this assumption is that increased fares at low fare levels should increase revenue; this will be true until the elasticity is one, after which fare increases will result in declining revenue. A commonly used (see Holmgren, 2007) functional form fulfilling this requirement is the semi-logarithmic model (e.g. Frankena, 1978; Dargay and Hanly, 2002). Assuming a semi-logarithmic functional form, the estimated demand function is:

$q_{i, t}=\alpha_{i} \cdot e^{\beta_{1} \cdot F_{i, t}} \cdot\left(\frac{V_{i, t}}{P_{i, t}}\right)^{\beta_{2}} \cdot A_{i, t}^{\beta_{3}} \cdot Y_{i, t}^{\beta_{4}} \cdot G_{t}^{\beta_{5}} \cdot e^{\varepsilon_{i, t}}$

where $\mathrm{q}$ is number of trips per capita, $\mathrm{F}$ is the public transport fare ${ }^{8}, \mathrm{~V}$ is the supply of vehicle kilometres, $\mathrm{P}$ is population, $\mathrm{A}$ is number of cars per capita, $\mathrm{Y}$ is average income and $G$ is the price of petrol. The indices $i$ and $t$ represents county and time period respectively

\footnotetext{
${ }^{5}$ See footnote 2 .

$E_{F}=\frac{\partial q}{\partial F} \frac{F}{q}$

${ }^{7}$ The model could also be expressed as: $\ln q=\ln \alpha+\beta_{1} \cdot F+\beta_{2} \ln \left(\frac{V}{P}\right)+\beta_{3} \ln A+\beta_{4} \ln Y+\beta_{5} \ln G+\varepsilon_{i, t}$

${ }^{8}$ Fares are approximated by revenue per trip.
} 
and $\varepsilon_{i, t}$ is an error term. It should be noted that the model contains county specific effects $\left(\alpha_{i}\right)$. These capture factors that vary between counties but are constant over time. The $\alpha_{i}: \mathrm{s}$ might also be called heterogeneity effects, as they capture the effects of all (time invariant) factors that might affect $q$ but who are not included in the other explanatory variables. In addition to county specific preferences, this can also capture the effects of different demographic structure, geography, infrastructure etc. The most significant advantage of this is that it is possible to obtain correct estimates for the parameters of the variables actually included in the model even if they are correlated with an unobserved (time invariant) effect. This is not possible if the variable is simply left out of the model altogether. (Wooldridge, 2002)

Total costs $(C)$ is explained by the supply of vehicle kilometres so that:

$$
C_{i, t}=c_{i}^{0}+c^{1} \cdot V_{i, t}+\eta_{i, t}
$$

The total cost in county i in year $t$ is therefore determined by a county specific constant $\left(c_{i}^{0}\right)$, that includes fixed costs and by the supply of vehicle kilometres. As seen in (2), the cost per vehicle kilometre is assumed to be the same in all counties which might be reasonable since fuel costs, maintenance costs and wages might not vary significantly between counties. Several alternative cost functions were however tested before arriving to the specification in (2). First, county specific constants as well as slope parameters were tried but the latter were not found to be statistically significant on any reasonable level when tested as a group. The model was also tested with a separate cost per vehicle kilometre for counties with large cities but this was not found statistically different from the other counties. ${ }^{9}$ This might appear strange but a large part of the differences between counties are probably captured by the county specific effects $\left(c_{i}^{0}\right)$ and although there are differences in wages they are relatively small in Sweden. At the same time, the levels of congestion are low to non-existent in most counties.

Public transport patronage is generally found to be highly correlated with vehicle kilometres or vehicle kilometres per capita, and one of them is often used as an explanatory variable in demand functions. The problem is that there are good reasons to believe that although quality of service, measured by vehicle kilometres, certainly affects demand, the level of demand also affects the level of service. This issue has been raised by several authors, the perhaps most influential being Mohring $(1972,1976)$ who showed that capacity and quality of service were joint products. His models have also been extended and generalized by Jansson $(1979,1984)$ and by Jara-Diaz and Gschwender (2003) Increasing (decreasing) capacity will also increase (decrease) the quality of service. This is most obvious when capacity is expanded by increasing the number of vehicles in use. In that case waiting times are reduced by shorter headway. (see also Nelson, 1972, Frankena, 1978 and Oum, 1992 for cases were this has been mentioned but not incorporated into the analysis) Despite this, the most common practice in statistical/econometric applications is to assume that quality cause demand and not the other way around. Failing to take into account a prevailing twoway relationship when estimating a demand model will result in biased estimates.

\footnotetext{
${ }^{9}$ Specifications with a time trend and time specific effects were also tested.
} 
Taking this into account, and at the same time acknowledging that the process of planning and implementing changes in a public transport system takes time (probably even more so in a system planned by a public authority who sets time tables for a year at a time), the longrun, or desired, level of supply in $\left(V_{i, t}^{*}\right)$ is assumed to be given by:

$V_{i, t}^{*}=k_{i} \cdot Q_{i, t}$

where $\mathrm{Q}$ is the total number of trips, i.e. $Q_{i, t}=q_{i, t} \cdot P_{i, t} \cdot \mathrm{k}$ can be thought of as the desired/required ratio between $\mathrm{V}$ and $\mathrm{Q}$. It reflects the fact that differences in county geography, city structure and demographics would make the same amount of vehicle kilometres result in different utilization in different counties. It might also reflect differences in service preferences between counties. It is also assumed that the actual, short run, supply is adjusted towards the desired level given by (3) by a fraction each time period and that it therefore can be explained by a partial adjustment model:

$V_{i, t}=\delta_{i} \cdot k_{i} \cdot Q_{i, t}+\left(1-\delta_{i}\right) V_{i, t-1}+\phi_{i, t}$

If all explanatory variables were strictly exogenous, the equations in this model could be estimated using the fixed effects estimator (FE) or the first difference estimator (FD). (Wooldridge, 2002) However, this is by definition not the case in this model. Vehiclekilometres is assumed to be affected by past levels of demand. Vehicle kilometres will then be correlated with the error term $\varepsilon$, thus violating the assumptions underlying both the FE and the FD estimator, rendering them both inconsistent. In order to handle that problem, the demand equation (1) and the supply equation (4) was estimated using instruments after transforming them into first differences. ${ }^{10}$ In the case of the demand equation, $\Delta F_{i, t}, \Delta \ln P_{i, t}$, $\Delta \ln A_{i, t}, \Delta \ln Y_{i, t}, \Delta \ln G_{i, t}, q_{i, t-1}$ and $q_{i, t-2}$ was used as instruments and in the supply equation $\Delta F_{i, t}, \Delta \ln P_{i, t}, \Delta \ln A_{i, t}, \Delta \ln Y_{i, t}, \Delta \ln G_{i, t}, V_{i, t-1}$ and $V_{i, t-2}$. (See Baltagi, 2001, Wooldridge, 2002, Hsiao, 2003 for more on panel data estimation)

The results from estimation of the demand equation (1) are shown in table 1. It can be seen that the elasticity with respect to vehicle kilometres is 0.26 which is lower than reported in many previous studies but this is in line with Holmgren (2007) showing that estimated elasticities with respect to vehicle kilometres are found to be lower in models trying to correct for a two-way relationship between supply and demand.

The elasticity with respect to fare vary with the fare level $\left(\mathrm{E}_{\mathrm{F}}=\beta_{1} F\right)$ and are for 2011 found to be between -0.16 in Stockholm to -0.54 in the county of Norrbotten which are in line with previous studies. (See Webster and Bly, 1980, Goodwin, 1992, Balcombe, et.al. 2004 and Holmgren, 2007 for summaries of previous studies)

\footnotetext{
${ }^{10}$ The demand equation would then be:

$\Delta \ln q_{i, t}=\beta_{1} \cdot \Delta F_{i, t}+\beta_{2} \Delta \ln \left(\frac{V_{i, t}}{P_{i, t}}\right)+\beta_{3} \Delta \ln A_{i, t}+\beta_{4} \Delta \ln Y_{i, t}+\beta_{5} \Delta \ln G_{i, t}+\Delta \varepsilon_{i, t}$
} 
Table 1. Results from estimation of the demand equation (1)

\begin{tabular}{|c|c|c|}
\hline Variable & Coefficient & Std. Error \\
\hline Fare & $-0.02 * * *$ & 0.001894 \\
\hline Vehicle kilometres & $0.26 * *$ & 0.101694 \\
\hline Car ownership & 0.21 & 0.380472 \\
\hline Income & 0.006 & 0.097430 \\
\hline Price of petrol & -0.07 & 0.057395 \\
\hline Obs $=533$ & $R^{2}-A d j=0.26$ & \\
\hline
\end{tabular}

None of the variables Car ownership, income or price of petrol is found to be statistically significant. The most surprising of these results is that car ownership does not appear to have a measurable effect on public transport usage. This might be due to the relatively small variations in car ownership in the material.

The results from estimation of the cost function (2) can be found in table 2. It can be seen that an increase in the production of vehicle kilometres by one, increases the costs by 21.03 SEK ${ }^{11}$.

\begin{tabular}{l} 
Table 2. Results from estimation of the cost function (2) \\
\begin{tabular}{|lcc|}
\hline Variable & Coefficient & Std. Error \\
\hline Vehicle kilometres & $21.03^{* *}$ & 8.41364 \\
& & \\
Obs $=565$ & $\mathrm{R}^{2}$-Adj $=0.14$ \\
\hline
\end{tabular} \\
\hline
\end{tabular}

The supply equation (4) is estimated for each county individually and the results are then used to calculate the county specific k:s which are shown in table 3 . It can be seen that the highest levels of vehicle kilometres required in order to cover demand are found in the large, sparsely populated northern counties of Västerbotten and Norrbotten.

\footnotetext{
11 SEK $=0.11 €$ (July 2013)

${ }^{12}$ Equation (2) was estimated using first differences and county specific effects are therefore not included in the table.
} 
Table 3. Estimated utilization, (k) from (4)

\begin{tabular}{|lclc|}
\hline County & $\mathbf{k}$ & County & $\mathbf{k}$ \\
\hline Stockholm & 0,4 & Älvsborg & 0,9 \\
Uppsala & 0,66 & Skaraborg & 0,63 \\
Södermanland & 1,2 & Värmland & 0,44 \\
Östergötland & 0,8 & Örebro & 0,77 \\
Jönköping & 0,3 & Västmanland & 1,46 \\
Kronoberg & 1,57 & Dalarna & 0,89 \\
Kalmar & 0,4 & Gävleborg & 1,24 \\
Gotland & 1,41 & Västernorrland & 1,03 \\
Blekinge & 0,53 & Jämtland & 0,84 \\
Kristianstad & 0,86 & Västerbotten & 1,78 \\
Malmö & 0,45 & Norrbotten & 1,85 \\
Halland & 0,36 & Skåne & 0,49 \\
Göteborgs län & 1,05 & Västra & \\
Göteborgs & & & 0,57 \\
stad & 0,39 & & \\
\hline
\end{tabular}

\section{Welfare maximizing policy}

Social welfare, or in the terminology of welfare theory, net social benefit (NSB) derived from a policy is the difference between the total willingness to pay and the costs associated with such policy (including external costs). Marginal willingness to pay is given be the inverse demand function and, if inputs are priced correctly, the costs of production is given by the cost function. (See e.g. Layard and Walters, 1978 or Zerbe and Dively, 1994 for general textbook discussions of welfare theory or Nash, 1978 for discussions concerning public transport) However, it is important to remember the consumer, in addition to paying the public transport fare $(\mathrm{F})$, also contributes with her time. Therefore, WTP is expressed in terms of generalized cost (GC) and user costs are included in the total costs. (Jansson, 1984, Jara-Diaz, 2007) NSB is: ${ }^{13}$

$$
N S B=\int_{0}^{Q} G C(Q) d Q-T C(Q)
$$

Where

$\mathrm{GC}=\mathrm{F}+\mathrm{AC}_{\text {user }}$

$\mathrm{AC}_{\text {user }}=$ Average user cost

$\mathrm{TC}=\mathrm{TC}_{\text {producer }}+\mathrm{TC}_{\text {user }}$

\footnotetext{
${ }^{13}$ Other variables might affect $\mathrm{F}$ but only policy relevant variables are shown here.
} 
Both producer and user costs are a function of $\mathrm{V}$ and therefore also ultimately of $\mathrm{Q}$ via the capacity requirement (3).

Equation (5a) can also be expressed as:

$N S B=\int_{0}^{Q} G C(Q) d Q-T C_{\text {producer }}-Q \cdot A C_{\text {user }}$

The condition for maximizing NSB is found by setting the derivative of (5) with respect to $Q$ equal to zero. The first order condition is therefore:

$\frac{\partial N S B}{\partial Q}=G C-M C_{\text {producer }}-\left(A C_{\text {user }}+Q \frac{\partial A C_{\text {user }}}{\partial Q}\right)=0$

Using (6) and the definition of GC, the familiar expression for optimal fare $\left(\mathrm{F}^{\mathrm{opt}}\right)$ is found:

$$
F^{o p t}=M C_{\text {producer }}+Q \frac{\partial A C_{\text {user }}}{\partial Q}
$$

Once the optimal fare is found, the welfare maximizing number of trips and supply of vehicle kilometres can be found through the demand function and the capacity requirement. Since user costs are generally falling when capacity is increased the last term in (7) is negative. (see e.g. Jansson 1984, Jara-Diaz, 2007)

Using the capacity constraint (3), and the cost function (2), $\mathrm{MC}_{\text {prod }}$ is given by:

$$
M C_{\text {prod }}=c^{1} \cdot k_{i}
$$

Using the empirical results presented in tables 2 and 3 in combination with (8) gives the marginal producer costs $\left(\mathrm{MC}_{\text {prod }}\right)$ which can be seen in Table 4. 
Table 4. Estimated marginal producer costs, 1 SEK $=0.11 €$ (July 2013)

\begin{tabular}{|l|c|l|c|}
\hline County & $\mathbf{M C}_{\text {prod }}$ & County & $\mathbf{M C}_{\text {prod }}$ \\
\hline Stockholm & 8,5 & Älvsborg & 18,91 \\
\hline Uppsala & 13,97 & Skaraborg & 13,32 \\
\hline Södermanland & 25,14 & Värmland & 9,25 \\
\hline Östergötland & 16,83 & Örebro & 16,23 \\
\hline Jönköping & 6,31 & Västmanland & 30,66 \\
\hline Kronoberg & 33,05 & Dalarna & 18,72 \\
\hline Kalmar & 8,41 & Gävleborg & 25,99 \\
\hline Gotland & 29,64 & Västernorrland & 21,61 \\
\hline Blekinge & 11,14 & Jämtland & 17,64 \\
\hline Kristianstad & 18,03 & Västerbotten & 37,53 \\
\hline Malmö & 9,46 & Norrbotten & 38,83 \\
\hline Halland & 7,57 & Skåne & 10,32 \\
\hline Göteborgs län & 22,15 & $\begin{array}{l}\text { Västra } \\
\text { götaland }\end{array}$ & 12,03 \\
\hline $\begin{array}{l}\text { Göteborgs } \\
\text { stad }\end{array}$ & 8,19 & & \\
\hline
\end{tabular}

Obtaining an estimate of the user cost component of (7) is more problematic, but given some assumptions, an approximation can be derived. Dividing $\mathrm{AC}_{\text {user }}$ into average costs for travel time $\left(A C_{\text {travel }}\right)$ and average costs for waiting and going to and from the bus-stops and/or terminals $\left(\mathrm{AC}_{\text {distr }}\right)^{14}$ and assuming that only the latter is affected by changes in $\mathrm{V}$ results in:

$F^{o p t}=M C_{\text {producer }}+Q \frac{\partial A C_{\text {distr }}}{\partial Q}$

Or, if it is assumed that $\mathrm{AC}_{\text {distr }}$ is linearly dependent on $\mathrm{V}$, in:

$F^{o p t}=M C_{\text {producer }}-A C_{\text {distr }}$

Using the average length of a public transport trip in each county, the proportion of bus and train trips in each county, the average speed of for local/regional bus and train and the average proportion of leisure and business trips in combination with the Swedish official values of time, an estimate of $\mathrm{AC}_{\text {travel }}$ was obtained. ${ }^{15}$ Based on Webster (1977) and Webster et al. (1985) $A C_{\text {distr }}$ is then assumed to be $97 \%$ of $A C_{\text {travel. }}$. This is obviously a very crude approximation based on older empirical data but it might nevertheless give some indication of the optimal fare. Some sensitivity analysis has been performed (see footnote 16) but this is definitely an area that should be improved in future research.

\footnotetext{
${ }^{14}$ distr stands for distribution.

${ }^{15}$ Average speed was obtained from UITP Mobility in cities database, data on average trip length and mode proportions was obtained from the Swedish governmental agency Transport analysis.
} 
In table 5, the estimated welfare maximising fares can be seen. In the cases where the calculated $\mathrm{AC}_{\text {distr }}$ exceeded $\mathrm{MC}_{\text {prod, }}$, the fare was set to zero and thereby excluding negative fares. In five counties, a zero fare is concluded whilst in the other counties the recommended change ranges from a decrease by $99 \%$ in Blekinge to an increase by $38 \%$ in Dalarna, although the latter case is actually the only one where an increase would be optimal. ${ }^{16}$

Table 5. Estimated optimal public transport fare $\left(F^{o p t}\right)$ in 2011 and the recommended change, 1 SEK = $0.11 €(\text { July 2013) })^{17}$

\begin{tabular}{|l|c|c|l|c|c|}
\hline County & F $_{\text {opt }}$ & $\begin{array}{l}\text { Change vs. } \\
\text { actual (\%) }\end{array}$ & County & F $^{\text {opt }}$ & $\begin{array}{l}\text { Change vs. } \\
\text { actual (\%) }\end{array}$ \\
\hline Stockholm & 3,70 & -56 & Örebro & 8,67 & -39 \\
\hline Uppsala & 1,43 & -93 & Västmanland & 20,74 & 38 \\
\hline Södermanland & 8,24 & -51 & Dalarna & 0 & -100 \\
\hline Östergötland & 7,41 & -45 & Gävleborg & 14,12 & -22 \\
\hline Jönköping & 0 & -100 & Västernorrland & 10,71 & -18 \\
\hline Kronoberg & 16,11 & -47 & Jämtland & 3,27 & -87 \\
\hline Kalmar & 0 & -100 & Västerbotten & 22,32 & -17 \\
\hline Gotland & 8,51 & -12 & Norrbotten & 24,68 & -10 \\
\hline Blekinge & 0,12 & -99 & Skåne & 1,67 & -90 \\
\hline Halland & 0 & -100 & Västra götaland & 4,73 & -52 \\
\hline Värmland & 0 & -100 & & & \\
\hline
\end{tabular}

As mentioned before, the welfare maximizing number of trips and supply of vehicle kilometres can be found through the demand function and the capacity requirement. In figure 4 , the results of implementing the welfare maximizing policy can be seen. The blue line with triangles in the figure indicate how the development of number of trips would have been if the policy had been implemented from 1986 and onwards. To obtain a fair baseline for comparison the actual policy, in terms of fares and supply levels, where used in the estimated demand function (1), the figures generated from that procedure is represented by the red line with squares in the figure. It can be seen that with the exception of the years 1988-1991 the suggested policy would have resulted in more public transport trips being made. For the entire period public transport trips per capita would on average have been $6.7 \%$ higher and it is above 10\% every year after 2000 (17.2\% in 2011).

Looking at the individual counties, a great deal of variation can be seen. Table 6 show the change in number of trips under the welfare maximizing policy in comparison to the actual policy in 2011 . The changes range from an increase of almost $44 \%$ in the county of Dalarna to a decrease of $11 \%$ in Jönköping. In most counties, 17 of 21 , the welfare maximizing policy would have increased the number of trips made in 2011. Due to the utilization requirement (k), table 6 also show the required changes in vehicle kilometres in each county in 2011. Most counties (17 of 21 ) can therefore be said to undersupply public transport service under

\footnotetext{
${ }^{16}$ It could be mentioned that if $A C_{\text {distr }}$ is instead assumed to be $50 \%$ of $A C_{\text {travel, }}$ fares should be reduced in 13 counties and if $75 \%$ is assumed, 18 counties should have lower fares than today.

${ }^{17}$ The counties Kristianstad and Malmöhus became part of Skåne County after 1998 and Älvsborg, Skaraborg and Göteborg became part of Västra götaland at the same time, they are therefore not included in the table.
} 
current policy and that welfare maximization therefore would require higher levels of service in those counties. However, Jönköping, Gotland, Gävleborg and Västernorrland, appear to be oversupplying presently

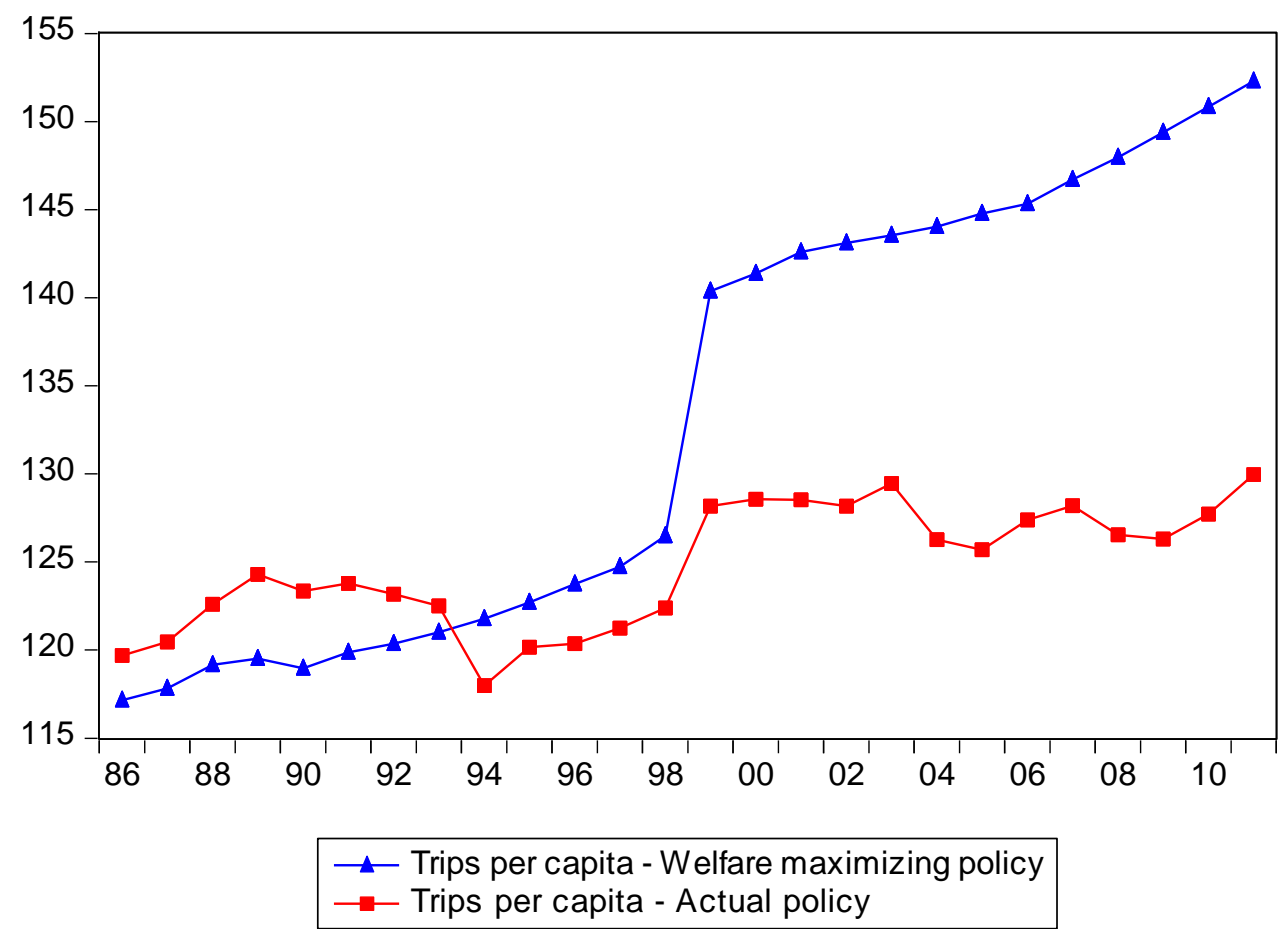

Figure 4. Estimated number of trips by public transport in Sweden under welfare maximizing policy and number of trips under actual (historic) policy

Table 6. Percentage change in number of trips and vehicle kilometres in 2011 due to welfare maximising policy

\begin{tabular}{|lc|lc|}
\hline County & $\begin{array}{l}\text { Change in trips and vehicle } \\
\text { kilometres (\%) }\end{array}$ & County & $\begin{array}{c}\text { Change in trips and vehicle } \\
\text { kilometres (\%) }\end{array}$ \\
\hline Stockholm & 19,5 & Örebro & 2,1 \\
Uppsala & 33,0 & Västmanland & 2,9 \\
Södermanland & 20,4 & Dalarna & 43,7 \\
Östergötland & 11,9 & Gävleborg & $-2,5$ \\
Jönköping & $-11,2$ & Västernorrland & $-4,8$ \\
Kronoberg & 29,2 & Jämtland & 33,7 \\
Kalmar & 0,6 & Västerbotten & 6,2 \\
Gotland & $-7,4$ & Norrbotten & 0,7 \\
Blekinge & 0,3 & Skåne & 24,9 \\
& & Västra & 11,7 \\
Halland & 7,0 & götaland & \\
Värmland & 1,6 & & \\
\hline
\end{tabular}

In the case of Stockholm, where the optimal supply of vehicle kilometres 2011 is found to be $20 \%$ above the actual level that year, it is important to remember that the model assumes that there are no external effects (that are not priced correctly). Therefore the model does not 
take into account that increasing public transport supply by that much might cause congestion. It might also be the case that there are technical limits to capacity making such a large increase in supply impossible.

\section{Concluding remarks}

This paper have been investigating the development of the Swedish local and regional public transport and evaluated the policy in comparison to a policy that would aim at maximizing social welfare. It was concluded that a welfare maximizing policy would require changes in both public transport fares and public transport supply in all counties. In all but one case, fares should be lower than they currently are and the supply of vehicle kilometres should be increased in 17 of 21 counties.

The suggested welfare maximizing policy is estimated to have increased the number of public transport trips by an average of $6.7 \%$ per year during $1986-2011$ and by $17.2 \%$ in 2011.

Even though the suggested policy would increase the need for subsidies to the public transport sector, it would increase welfare and overall public transport usage which would appear to be in line with official policy.

\section{References}

Act 1978:438, om huvudmannaskap för viss kollektiv persontrafik, (in Swedish)

Act 1979:558, om ansvar för viss kollektiv persontrafik, (in Swedish)

Alexandersson, G. (2010). The Accidental Deregulation - Essays on Reforms in the Swedish Bus and Railway Industries 1979-2009. PhD Thesis, Stockholm School of Economics

Balcombe, R., Mackett, R., Paully, N., Preston, J., Shires, J., Titheridge, H., Wardman, M., \& White, P. (2004). The demand for public transport: A practical guide. Report TRL593. Wokingham, UK: TRL

Baltagi, B. (2001). Econometric analysis of panel data. New York: John Wiley \& Sons

Bös, D. (1978). Distributional effects of maximisation of passenger miles. Journal of Transport Economics and Policy, 12, 322-329

Dargay, J., \& Hanly, M. (2002). The demand for local bus services in England. Journal of Transport Economics and Policy, 36, 73-91

Frankena, M. W. (1978). The demand for urban bus transit in Canada. Journal of Transport Economics and Policy, 12, 280-303

Glaister, S., \& Collings, J. J. (1978). Maximisation of passenger miles in theory and Practice. Journal of Transport Economics and Policy, 12, 304-321 
Goodwin, P. B. (1992). A review of new demand elasticities with special reference to short and long run effects of price changes. Journal of Transport Economics and Policy, 26, $155-169$

Government proposition 2008/09:93, Mål för framtidens resor och transporter (in Swedish)

Hansson, L. (2011). The tactics behind public transport procurements: an integrated actor approach. European Transport Research Review. 3, 197-209

Hensher, D. (2008). Assessing systematic sources of variation in public transport elasticities: some comparative warnings. Transportation Research Part A, 42, 1031-1042

Holmgren, J. (2007). Meta-analysis of public transport demand. Transportation Research Part A, 41, 1021-1035

Holmgren, J., Jansson, J. O., \& Ljungberg, A. (2008), Public transport in towns - inevitably on the decline? Research in Transportation Economics, 23, 65-74

Hsiao, C. (2003). Analysis of panel data. Cambridge, UK: Cambridge University Press

Jansson, K. Wallin, B. (1991) Deregulation of Public Transport in Sweden. Journal of Transport Economics and Policy. 97-107

Jansson JO (1979) Marginal cost pricing of scheduled transport services. A development and generalisation of Turvey and Mohring's theory of optimal bus fares. J Transp Econ Policy, 13:268-294

Jansson JO (1984) Transport system optimization and pricing. Wiley, Chichester

Jara-Diaz, S (2007) Transport Economic Theory, Bingley, UK, Emerald

Layard, R, Walters, A. (1978), Micro-Economic Theory, New York, USA, McGraw Hill

Ljungberg, A. (2007). Lokal kollektivtrafik på samhällsekonomisk grundval. Ph.D. thesis. Linköping, Sweden: IEI, Linköping University

Nash, C. A. (1978). Management objectives, fares, and service levels in bus transport. Journal of Transport Economics and Policy, 12, 70-85

Nash, C. A. (1982). Economics of Public Transport, London, Longman

Nelson, G. (1972). An econometric model of urban bus transit operations. Ph.D. thesis. Houston, TX: Rice University

Macario, R. (2001) Managing and assessing regulatory evolution in local public transport operations in Europe, Paper presented at the 7th international conference on competition and ownership in land passenger transport, Thredbo 7. Molde, Norway

Mohring H (1972) Optimization and scale economies in urban bus transportation. American Economic Review, 62:591-604 
Mohring H (1976) Transportation economics. Ballinger Press, Cambridge

Oum, T. H., Waters, W. G., \& Yong, J. S. (1992). Concepts of price elasticities of transport demand and recent empirical estimates. Journal of Transport Economics and Policy, 26,139-154

Webster, V (1977) Urban passenger transport, some trends and prospects. Transport and Road Research Laboratory, Crawthorne, UK

Webster, F. V., \& Bly, P. H. (1980). The demand for public transport. Report of the international collaborative study of the factors affecting public transport patronage. Wokingham, TRL, UK

Webster, F V. Bly, P H. Johnston, R H. Paulley, N Dasgupta, M (1985) Changing patterns of urban travel, European Conference of Ministers of Transport

Wooldridge, J. M. (2002). Econometric analysis of cross section and panel data. Cambridge, MA: The MIT Press

Zerbe, R. Dively, D. (1994), Benefit-Cost Analysis: In theory and Practice, New York, USA, Harper Collins 